\title{
Cooperative and individualistic functions of the microRNAs in the miR-23a 27a 24-2 cluster and its implication in human diseases
}

\author{
Ravindresh Chhabra, Richa Dubey, Neeru Saini
}

\begin{abstract}
The small RNA molecules of about 19-22 nucleotides in length, aptly called microRNAs, perform the task of gene regulation in the cell. Interestingly, till the early nineties very little was known about them but eventually, the microRNAs have become forefront in the area of research. The huge number of microRNAs plus each one of them targeting a vast number of related as well as unrelated genes makes them very interesting molecules to study. To add to the mystery of miRNAs is the fact that the same miRNA can have antagonizing role in two different cell types i.e. in one cell type; the miRNA promotes proliferation whereas in another cell type the same miRNA inhibits proliferation. Another remarkable aspect of the microRNAs is that many of them exist in clusters. In humans alone, out of 721 microRNAs known, 247 of them occur in 64 clusters at an inter-miRNA distance of less than 5000bp. The reason for this clustering of miRNAs is not fully understood but since the miRNA clusters are evolutionary conserved, their significance cannot be ruled out. The objective of this review is to summarize the recent progress on the functional characterization of miR-23a 27a 24-2 cluster in humans in relation to various health and diseased conditions and to highlight the cooperative effects of the miRNAs of this cluster.
\end{abstract}

\section{Introduction}

MicroRNAs (miRNAs) are non-coding RNAs which are initially transcribed from genomic DNA to long primary transcripts (pri-miRNAs) and then are cleaved by nuclear Drosha into 60-70 nucleotide hairpin-shaped precursor RNAs (pre-miRNAs) [1,2]. Pre-miRNAs are exported to the cytoplasm by Ran-GTP and Exportin-5 $[3,4]$. Once in the cytoplasm, the pre-miRNAs are cleaved by dicer into 22 nucleotide mature miRNA duplexes [5,6]. In association with RNA-induced silencing complex (RISC), one strand of the miRNA duplex binds to the target mRNA sequence in the 3'UTR (untranslated region). This binding finally leads to either the translational repression or degradation of the target mRNA.

The first micro RNA (lin-4) was found in C. elegans in 1993 [7] and since then thousands of miRNAs have been discovered in different species. In humans alone, 721 miRNAs have been identified till date [8]. Out of

\footnotetext{
* Correspondence: nsaini@igib.in

Functional Genomics Unit, Institute of Genomics and Integrative Biology (CSIR), Mall Road, Delhi-110007, India
}

these, 247 miRNAs have been found to occur in 64 clusters at an inter-miRNA distance of less than 5000bp [8] and since most of these clusters show a higher degree of evolutionary conservation [9], it indicates that the clustering propensity of miRNAs might be mediating biological role. miRNAs are encoded in diverse genomic locations including intergenic regions, introns of protein-coding genes and introns/exons of noncoding RNA genes [8]. Literature suggests that a single miRNA can regulate many mRNA targets, and several miRNAs can regulate a single mRNA. They are involved in a variety of functions, including developmental transitions, neuronal patterning, apoptosis, adipogenesis metabolism and hematopoiesis in different organisms. Many independent studies have provided evidence for the possible association of miRNA(s) with several human malignancies and infectious diseases [10-12].

The miR-23a 27a 24-2 cluster is found to have altered expression in many diseased states (Table 1). This cluster has been shown to give rise to contrasting phenotypes in different cell types [13,14]. Several studies have also linked the expression of this cluster to cell cycle, proliferation, differentiation, haematopoesis and 
cardiac hypertrophy [13,15-17] to name a few, thereby indicating that miR-23a 27a 24-2 cluster controls several processes during health and diseases. Infact, this cluster was the first downstream miRNA target implicated in regulating the development of myeloid versus lymphoid cells [18]. It is well documented that all three miRNAs of this cluster are derived from a single primary transcript but depending on different biological conditions their expression pattern varies i.e. in some instances all three have similar expression pattern and in some one or two of these miRNA are expressed and the third is not (Table 1). Such complex expression pattern and association with diseased states makes it a very interesting subject for research. The objective of this review is to summarize the current knowledge about the miRNAs of miR-23a 27a 24-2 cluster in relation to

Table 1 The pathological conditions in which miRNAs of miR-23a 27a 24-2 cluster are implicated [102] (u - up, d - down, u/d - up in one study and down in another, NA - up/down is not known)

\begin{tabular}{|c|c|c|c|c|c|c|}
\hline Diseased condition & $23 a$ & $27 a$ & 24 & $23 b$ & $27 \mathrm{~b}$ & Reference \\
\hline $\begin{array}{l}\text { Acute lymphoblastic leukemia } \\
\text { (ALL) }\end{array}$ & $\mathrm{u}$ & $\mathrm{u}$ & $\mathrm{u}$ & $\mathrm{u}$ & u & [28] \\
\hline Acute myeloid leukemia (AML) & u & u & u & u & u & [28] \\
\hline $\begin{array}{l}\text { Acute promyelocytic leukemia } \\
\text { (APL) }\end{array}$ & $d$ & $d$ & $d$ & & & [41] \\
\hline Autism spectrum disorder (ASD) & $d$ & $d$ & & & & [103] \\
\hline Bladder cancer & $\mathrm{u}$ & & & u & & [42] \\
\hline Breast cancer & & u & & & & {$[15,50]$} \\
\hline Cardiac hypertrophy & $\mathrm{u}$ & $\mathrm{u}$ & $\mathrm{u}$ & u & $\mathrm{u}$ & {$[17,104]$} \\
\hline Colorectal cancer & $d$ & $d$ & $\mathrm{u}$ & & $d$ & {$[33,105]$} \\
\hline Gastric cancer (stomach) & u & u & $\mathrm{u}$ & & & {$[32,33]$} \\
\hline Glioblastoma & $\mathrm{u}$ & & u & $\mathrm{u}$ & & {$[106]$} \\
\hline Heart failure & $\mathrm{u}$ & & u & u & & [107] \\
\hline Hepatocellular carcinoma (HCC) & u & u & u & & & [13] \\
\hline Kidney cancer & & $\mathrm{u}$ & & & & [108] \\
\hline Lung cancer & & & u & & $\mathrm{d}$ & {$[109]$} \\
\hline Lupus nephritis & & & & & & {$[110]$} \\
\hline Malignant melanoma & & $d$ & & $d$ & & [111] \\
\hline $\begin{array}{l}\text { Oral squamous cell carcinoma } \\
\text { (OSCC) }\end{array}$ & $d$ & $d$ & & & $d$ & {$[112]$} \\
\hline Pancreatic cancer & $\mathrm{u}$ & & u & u & & {$[29,113]$} \\
\hline $\begin{array}{l}\text { Papillary thyroid carcinoma } \\
\text { (PTC) }\end{array}$ & & & $\mathrm{u}$ & & & [114] \\
\hline Prostate cancer & $\mathrm{u} / \mathrm{d}$ & $\mathrm{u} / \mathrm{d}$ & $\mathrm{u}$ & $u / d$ & $\mathrm{u} / \mathrm{d}$ & {$[115,116]$} \\
\hline Schizophrenia & & & $d$ & & & {$[117]$} \\
\hline Serous ovarian cancer & $\mathrm{u}$ & $\mathrm{u}$ & & $\mathrm{u}$ & & {$[118]$} \\
\hline Ulcerative colitis (UC) & u & & u & u & & [119] \\
\hline Uterine leiomyoma (ULM) & & $\mathrm{u}$ & & $\mathrm{u}$ & & {$[120]$} \\
\hline Vesicular stomatitis & & & NA & & & {$[121]$} \\
\hline
\end{tabular}

various health and diseased conditions and to highlight the cooperative effects of the miRNAs of this cluster.

\section{miR-23 cluster paralogs}

Ancient gene duplications have given rise to miR-23 cluster paralogs in mammals: miR-23a 27a 24-2 cluster (localized on chromosome 9q22) is intergenic and its paralog miR-23b 27b 24-1 cluster (localized on chromosome 19p13) is intronic. It is not uncommon for miRNA clusters to have homologs and paralogs as shown by Yu et al in 2006 [19]. The miR-23a 27a 24-2 cluster encodes pri-miRNA transcript composed of 3 miRNAs: miR-23a, miR-27a and miR-24. Mature sequence of miR-23a and miR-27a differ by just one nucleotide in comparison to their paralogs miR-23b and miR-27b while the mature sequence of miR-24-1 and miR-24-2 is same. Since the mature sequence of paralogous miRNA is similar, one might speculate that they have overlapping targets. The miRNA target prediction software, TargetScan does predict common targets of miR-23a and miR-23b and miR-27a and miR-27b, and there are also reports where both the isoforms (27a \& $27 \mathrm{~b}$ or $23 \mathrm{a} \& 23 \mathrm{~b}$ ) are simultaneously up regulated and down regulated (Table 1 ). The targets may be shared but since the paralogous clusters are present on different chromosomes and are produced from different transcripts, their regulation might be independent of each other. Hence, the functional differences between them would be because of differential regulation of their expression and processing rather than different portfolios of their potential targets [20]. Such duplication of miRNA cluster would lead to very rigid control of the targets of this cluster. But to decipher why such duplication occurred in the first place, one needs to study the evolution of this cluster. To understand the evolution of miR-23a and -23b clusters, we looked for their presence in different organisms (Fig. 1a, Additional File 1). We observed that these clusters are known to be present only in vertebrates and there are certain differences across species which are easily seen in the Additional File 1 . However, very extensive study needs to be done to work out the evolution of these clusters. One such study has been done for miR-17 cluster which has 3 paralogous cluster, one each on chromosome 7, 13 and $x$ by Tanzer et al in 2004 [21]. They have described DDC (duplication-degeneration-complementation) model for the evolution of miR-17 cluster which predicts that after a gene duplication either one of the two paralogs is lost or, if both are retained, then the two paralogs will evolve to perform complementary subfunctions. The model further predicts that duplicate clusters that still contain redundant miRNAs should differ in their spatio-temporal expression patterns. Extrapolating these findings on miR-23a and miR-23b cluster, 


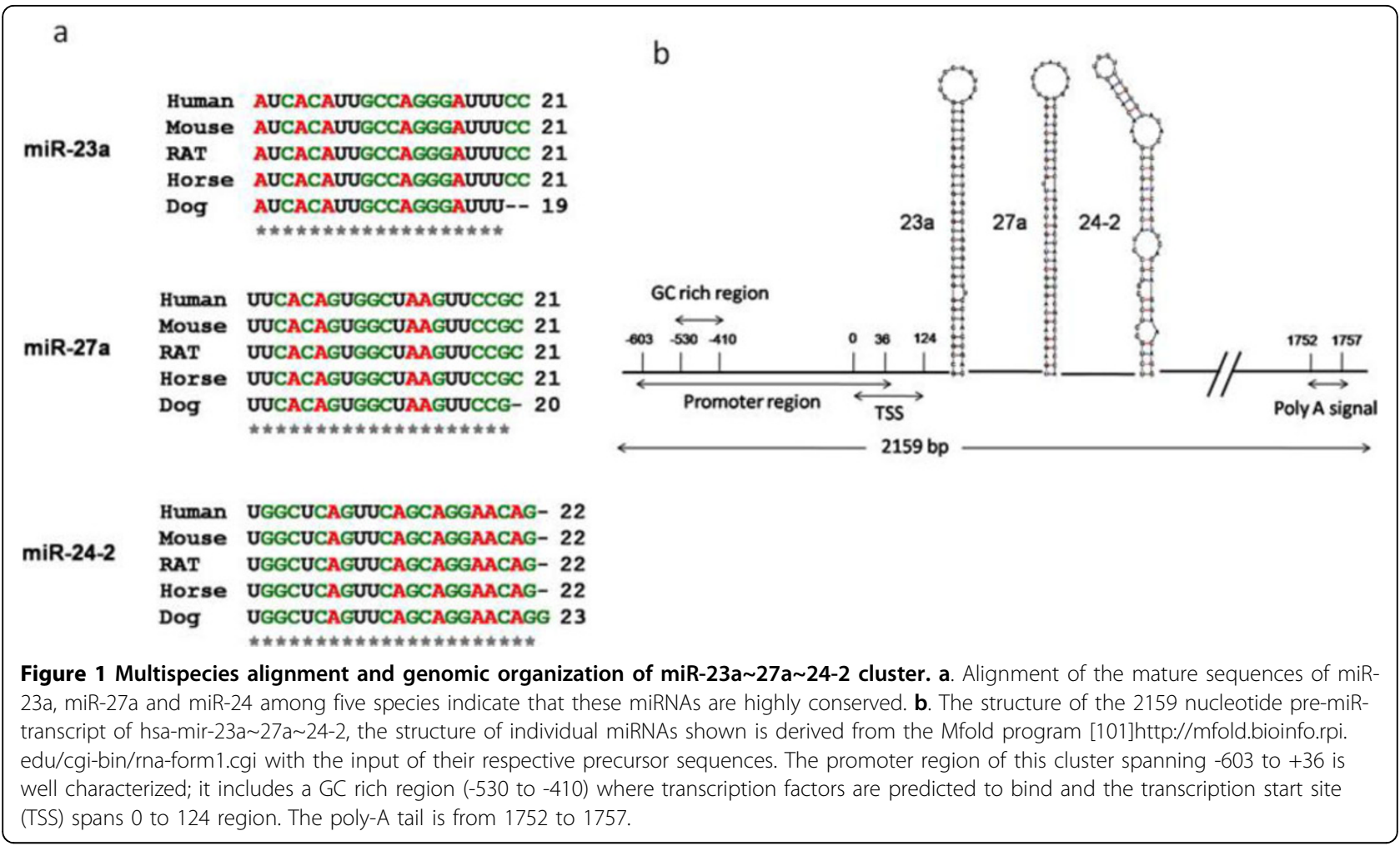

one can say that herein both the paralogous clusters were retained that differ in their expression profiles and perform complementary functions.

The expression consistency of miRNAs in a miR-23 cluster has been shown in several studies (Table 1) but the cooperativity between them is yet to be worked out. Consistent with these studies, there is also a report which shows that miRNAs of a miRNA cluster might work in combination to accomplish their function [22]. Nevertheless, inconsistent expression of the miRNA members of miR-23 cluster has also been observed. $\mathrm{Yu}$ et al found miR-23a/23b cluster to be inconsistent while studying human miRNA clusters in six hematopoietic cell lines [19]. There was no detectable expression of miR-23b, miR-27b and miR-24 in all 6 cell lines (3D5, Jurkat, K562, CMK, HL-60, U937) but miR-23a and miR-27a was detected with similar expression levels in 4 cell lines (3D5, K562, HL-60, U937). This may be caused by their independent transcription or because they are transcribed together but processed by additional post transcriptional regulation mechanism.

\section{Regulation of the miRNA cluster}

The primary transcript of miR-23a 27a 24-2 cluster is around $2.2 \mathrm{~kb}$ long [23]. It has been observed that miR23a 27a 24-2 cluster gene lacks long open reading frame and the short open reading frame found does not code for any protein. Lee et al in 2004 showed for the first time that like protein-coding genes, the transcription of miR-23a 27a 24-2 cluster can be Pol II dependent [23]. Infact the region covering -603 and +36 bp contains the promoter of miR-23a 27a 24-2 cluster. It was also observed that the promoter of miR23a 27a 24-2 cluster lacks both the known common as well as less common promoter elements such as TATA box, the initiator element, the downstream promoter element (DPE), or the TFIIB recognition element (BRE), downstream core element (DCE), and the MED-1 (multiple start site element downstream) [24]. It is not surprising as more than $80 \%$ of mammalian protein coding genes are driven by TATA less promoter. The nucleotide sequence of the promoter shows that the region covering -530 to -410 of the cluster is GC rich and contains at least two GC boxes and probably this is the site where transcription factor (s) binds [25]. They also observed that the miR-23a 27a 24-2 promoter is different from the promoters of RNA pol II transcribed snRNA genes as it lacks the proximal sequence element (PSE) too.

The schematic structure of miRNA cluster along with the promoter binding region has been shown in Fig. $1 \mathrm{~b}$.

Interestingly, even after the primary transcript of miRNA cluster is made, there is no guarantee that all three miRNAs will be formed proportionally. Previously, in a study done by our group we have observed increased expression of miR-27a as well as miR-24-2 but 
not of miR-23a after the over expression of miR23a 27a 24-2 cluster in HEK293T cells [14]. In support to our findings there are reports in the literature. Buck et al also recently observed that down-regulation of miR-27a occurs independently from miR-23a and miR24 [26]. In an independent study, Lee et al had previously observed a block in the processing of primiR-23a to mature miR-23a in HEK293 cells but not in HeLa cells and undifferentiated P19 cells [27]. Moreover inconsistent expression of the miRNA members of miR23 cluster has also been observed. It seems that both transcriptional and post transcriptional mechanisms could be responsible for differential expression of miRNAs located within the same genomic cluster. All this indicates that the miRNAs of this cluster are under complex regulatory mechanisms which can act even after the primary transcript of miR-23a 27a 24-2 has been made.

\section{Functions of the miR-23a 27a 24-2 cluster miR-23a 27a 24-2 cluster in tumorigenesis}

Deregulation of microRNA(s) has been found in wide range of human diseases including cancer. However, it is not clear whether the observed change in the expression profile is a cause or consequence of pathological processes. Additionally, miRNA profiling studies have revealed that in various diseased conditions, all the three microRNAs of the miR-23a 27a 24-2 cluster are simultaneously deregulated (Table 1). Although, their significance is yet to be worked out in these conditions, but the simultaneous increase or decrease of mir-23a, miR27a and miR-24-2 point towards their cooperative role in carrying out their functions in the diseased conditions. Expression of miR-23a 27a 24-2 cluster has been found to be up-regulated in acute lymphoblastic leukemia [28], acute myeloid leukemia [29], chronic lymphocytic leukemia [30], breast cancer [31], gastric cancer $[32,33]$, cholangiocarcinoma cells [34] and hepatocellular carcinoma cells (HCC) [13] as compared to their respective normals. In accordance with the tumorigenic activity, Huang et al in 2008 found that over expression of miR-23a 27a 24-2 cluster could promote HCC cell growth and attenuate TGF- $\beta$-induced apoptotic cell death [13]. It has been observed that progressive tumors show high CDK2/4 activity, which could phosphorylate and inhibit the transcriptional activity of SMAD3, thus conferring cancer cells to escape from TGF- $\beta$ - induced tumor suppression. Recently, Rogler et al in 2009 [35] has reported miR-23b cluster targets Smad 3, 4, and 5. The coordinate targeting of Smad3 mRNA by miR-23a cluster and miR-23b cluster adds an evolutionary advantage. Generally individual miRNAs have a weak role in knocking down gene expression [36,37] and an amplification scheme may be necessary to bring a complex and powerful signaling network such as TGF- $\beta$ to a rapid halt [38]. In addition to the above, the role of miR23a 27a 24-2 cluster has also been observed in metastasis and liver cirrhosis [13]. Cameron et al observed elevated expression of miR-23a, miR-24 and miR-27a in type III versus type I EBV (Epstein-Barr virus) latency [39]. The authors suggested that EBV-mediated regulation of cellular miRNAs may contribute to EBV signaling and might be associated with lymphoid and epithelial cancers. Table 1 lists the diseases where these miRNA have been implicated.

In contrast to the above cited studies on the widespread evidence of the increased expression of 23a 27a 24-2 cluster in various cancers, recently we observed that the over expression of miR-23a 27a 24-2 cluster in human embryonic kidney cells (HEK293T cells) induces apoptosis by caspase-dependent as well as caspase-independent pathway. Pro and anti-apoptotic nature of the miR-23a 27a 24-2 cluster suggest that this cluster may exhibit context-dependent functions and warrants urgent need to identify its molecular functions in humans, especially the downstream targets of this cluster.

\section{Function of the individual members of the miR- 23a 27a 24-2 cluster miR-23a}

miR-23a is the first member of the mir-23a 27a 24-2 cluster. So far, miR-23a has been implicated in several cancers, cardiac hypertrophy and muscular atrophy (Fig. 2).

miR-23a in cancer During cancer, oncogenic transcription factor c-Myc regulates the glutamine catabolism in addition to the regulation of cell cycle and glucose metabolism. Myc's role in stimulating glutamine catabolism has been, in part attributed through the repression of miR-23a and miR-23b. miR-23b originates from miR23b 27b 24-1 cluster and has one nucleotide difference in the mature sequence in comparison to the mature sequence of miR-23a. Gao et al in 2009 observed that increase in C-Myc in human P-493 B lymphoma cells and PC3 prostate cancer cells leads to suppression of $\mathrm{miR}-23 \mathrm{a} / \mathrm{b}$ which in turn results in greater expression of their target protein, mitochondrial glutaminase, which is required for bioenergetics, nucleotide biosynthesis and redox homeostasis in cancer cells [40]. Saumet et al in 2008 observed that miR-23a 27a 24-2 is directly repressed by the PML-RARA oncogene [41]. The PMLRARA oncogene is formed by the chromosomal translocation that fuses the gene encoding the retinoic acid receptor alpha (RARA) with the promyelocytic leukemia protein (PML) gene. This fused PML-RARA oncogene is associated with acute promyelocytic leukemia (APL) and is responsible for increasing the expression of key cancer proteins in APL. 


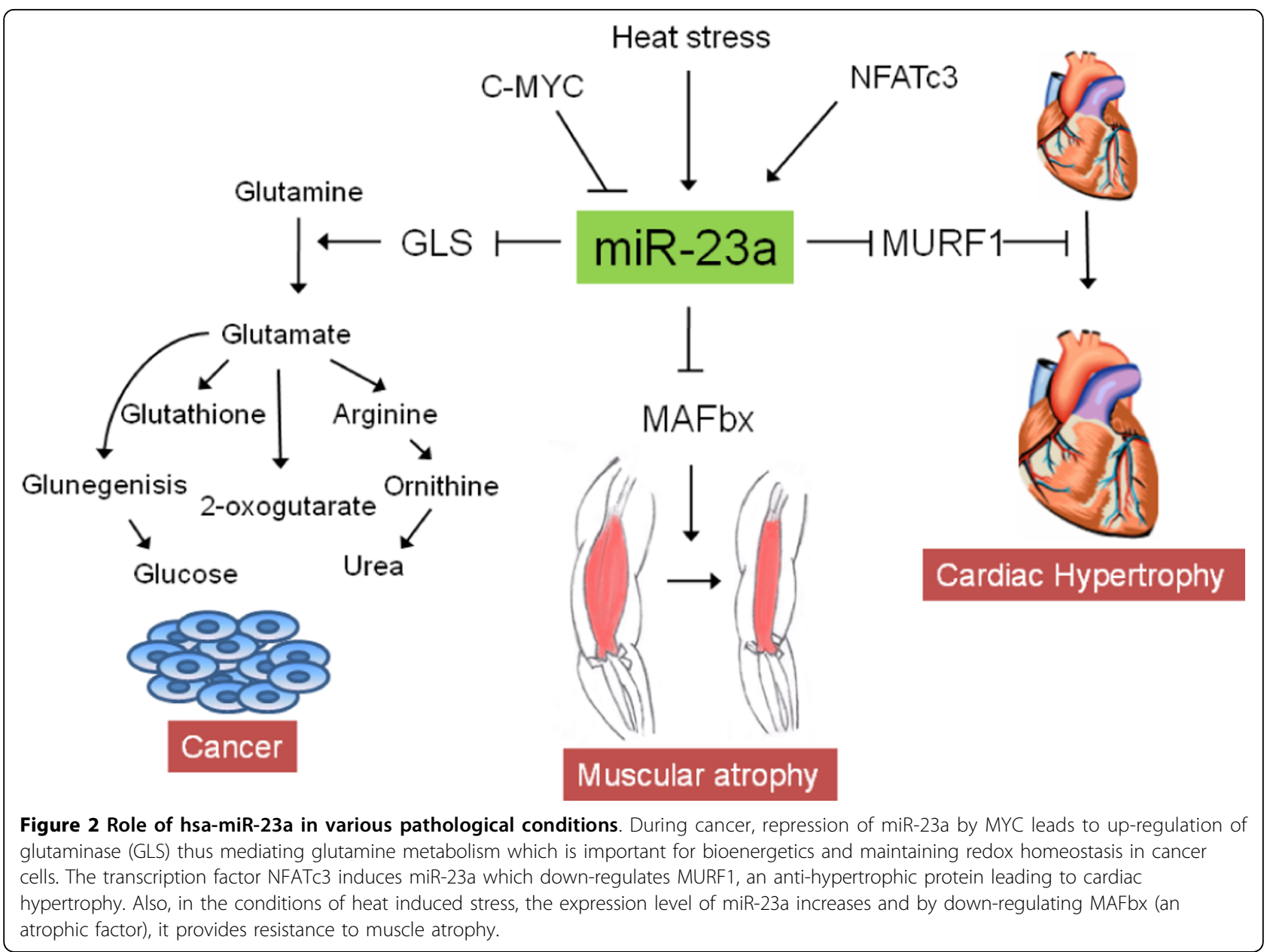

On the contrary, there are a few reports wherein upregulation of miR-23a has been observed in cancers. Significant up-regulation of miR-23a (and miR-27a) was reported by Meng et al in human bladder cancer [42] and by Gottardo et al in malignant cholangiocytes in comparison to their normal tissues [34]. Furthermore, Mi et al in his study showed that miR-23a along with miR-24 and miR-27a are also among several other miRNAs that have been differentially expressed between acute myeloid leukemia (AMLs) and acute lymphoblastic leukemia (ALLs) [28]. Apart from these, up-regulation of miR-23a/b along with miR-24 has also been reported in osteoblast cell line [43].

Although the increase/decrease of miR-23a has been reported in most of the studies related to cancer but it is as yet unknown whether it is a cause or effect of the disease. Apart from playing a role in cancer metabolism, selective expression of miR-23a along with miR-24 has been shown in microvascular endothelial cells in vivo [44]. Also, miR-23a may play a role in angiogenesis as it is among the highly expressed miRNAs in human umbilical vein endothelial cells (HUVECs) [45]. It seems that a re-evaluation of cancer metabolism considering glutamine catabolism along with selective expression of miRNAs in the vasculature is needed before cancer can be effectively targeted in therapy.

miR-23a in cardiac hypertrophy Cardiac hypertrophy is thickening of heart muscle resulting in decrease in size of the ventricles. It occurs in response to stress conditions like hypertension, the heart muscle damage and is an early indication of most of the heart diseases $[46,47]$. Lin et al in their study reported that miR-23a is a pro-hypertrophic miRNA, and its expression is regulated by the transcription factor, nuclear factor of activated $\mathrm{T}$ cells (NFATc3) [17]. They found that NFATc3 could directly activate miR-23a expression through the transcriptional machinery. Interestingly the muscle specific ring finger protein 1 (MuRF1), an anti-hypertrophic protein, has been identified as a target of miR-23a. It seems miR-23a conveys the hypertrophic signal by suppressing the translation of MuRF1. It was also observed that it is only miR-23a and not miR-27a and miR-24 which participate in initiating hypertrophy induced by hypertrophic stimuli including isoproterenol and 
aldosterone. The up-regulation of the other two miRNAs clustered with miR-23a, miR-27a and miR-24 occurred much later. It was suggested by the authors that since miR-23a is located closer to the transcription start site (TSS), the effect must be reaching the miR-23a first and later to other miRNAs.

miR-23a in muscle atrophy Skeletal muscle atrophy is observed in many physiological and pathological settings including fasting, several chronic diseases like cancer, diabetes, AIDS, sepsis, and sarcopenia. During atrophy, atrophic factors up-regulate the muscle-specific F-box protein MAFbx/atrogin-1. Wada et al in 2008 observed that miR-23a plays anti-atrophic effect. It has been observed that miR-23a suppresses MAFbx/atrogin-1 translation by binding to 3' UTR of the mRNA and forced expression of miR-23a in myotubes and myofibers results in resistance to muscle atrophy [48].

The control of genes with antagonizing functions [cardiac hypertrophy (increased cell growth) and muscle hypertrophy (reduced cell growth)] may underlie the complex and conflicting effects of miR-23a.

\section{miR-27a}

miR-27a is the microRNA sandwiched between the miR23a and miR-24-2. Its paralogue, miR-27b originates from miR-23b 27b 24-1 cluster. Some of the cellular targets of miR-27a are those that can impact cell cycle regulation, proliferation, apoptosis and differentiation (Fig. 3)

miR-27a in cancer and multidrug resistance of cancer Oncogenic role of miR-27a is confirmed by several experimental studies. miR-27a is significantly up-regulated in renal cell carcinoma [42], in cervical cancer [49], in gastric adenocarcinoma [32] and in breast cancer $[15,50]$. miR-27a is also involved in Helicobacter pylori induced infection and gastric cancer [51]. It has been found that in gastric cancer cells, miR-27a promotes the tumor development by targeting a tumor suppressor prohibitin, an evolutionary conserved and ubiquitous protein interacting with $\mathrm{pRb}$ and its family members [32]. In breast cancer cells, miR-27a functions as an oncogene by indirectly enhancing the expression of specificity protein $(\mathrm{Sp})$ transcription factors. Sp factors have also been found to be over expressed in tumours where they contribute to the proliferative and angiogenic phenotype associated with cancer cells by regulating number of angiogenic proteins like vascular endothelial growth factor (VEGF), VEGF receptor 1 (VEGFR1, Flt-1), VEGFR2 (KDR) and the antiapoptotic gene survivin [52-55]. miR-27a down-regulates the repressor of the Sp proteins, ZBTB10/RINZF (a putative zinc finger and BTB domain containing protein) in both MDA-MB-231 breast cancer cells [15] and SKBr3 breast cancer cells [56].

miR-27a also contributes to oncogenesis by regulating cell cycle progression. It was observed that inhibition of
miR-27a increased the percentage of cells in G2-M phase. This arrest was attributed to the induction of Myt-1 [15], which is responsible for phosphorylation of CDC2 resulting in inhibition of $\mathrm{CDC} 2 /$ cyclin $\mathrm{B}$ dependent initiation of mitosis [57-59]. The study by Chintharlapalli et al in 2009 showed that repression of miR-27a leading to the induction of ZBTB10 and Myt-1 was the cause behind apoptotic and anti-carcinogenic activity of Methyl 2-cyano-3,11-dioxo-18 $\beta$-olean-1,12dien-30-oate (CDODAMe) in colon cancer cells [60].

Guttilla et al had shown in 2009 that miR-27a along with miR-96, and miR-182 down-regulates FOXO-1 protein, a transcription factor that orchestrates the regulation of genes involved in the apoptotic response, cell cycle checkpoints, and cellular metabolism [50]. These three microRNAs, miR-27a, miR-96 and miR-182, were observed to be highly expressed in MCF-7 breast cancer cells, in which the level of FOXO1 protein is very low. It was also observed that over expression of FOXO1 resulted in decreased cell viability because of inhibition of cell cycle traverse and induction of cell death. It seems that targeting of FOXO1 by microRNAs may contribute to transformation or maintenance of an oncogenic state in breast cancer cells.

Apart from suppressing ZBTB10/RINZF and FOXO-1, miR-27a contributes to oncogenesis by negatively regulating RYBP/DEDAF, an apoptotic facilitator as has been reported in SKBr3 cells [56].

In addition to the oncogenic activity, miR-27a also regulates multidrug resistance. In two separate studies, it was shown that the down-regulation of miR-27a leads to decrease in the expression of multidrug resistance gene (MDR1/P-glycoprotein/ABCB1) [61,62]. Down-regulation of miR-27a also caused a decrease in Bcl-2 expression and increase in the Bax expression, thereby leading the cancerous cells towards apoptosis [62]. Also, Sun et al showed that genistein significantly inhibited growth of uveal melanoma cells and affects miR-27a and target gene expression [63]. Very recently van Jaarsveld et al has found significant association between miR-27a and chemotherapy resistance in ovarian cancer [64].

Furthermore while studying the effect of SNPs in miRNAs, Yang et al in their study found that the SNP rs895819, located in the terminal loop of pre-miRNA$27 \mathrm{a}$, showed a protective effect in a large familial breast cancer study [65]. They also show that artificial mutations in the terminal loop of miR-27a can block the maturation process of the miRNA. They hypothesized that the G-variant of rs895819 might impair the maturation of the oncogenic miR-27a and thus, is associated with familial breast cancer risk. In an independent study, significant association between miR-27a polymorphism and gastric mucosal atrophy has been observed in Japanese male subjects [66]. 


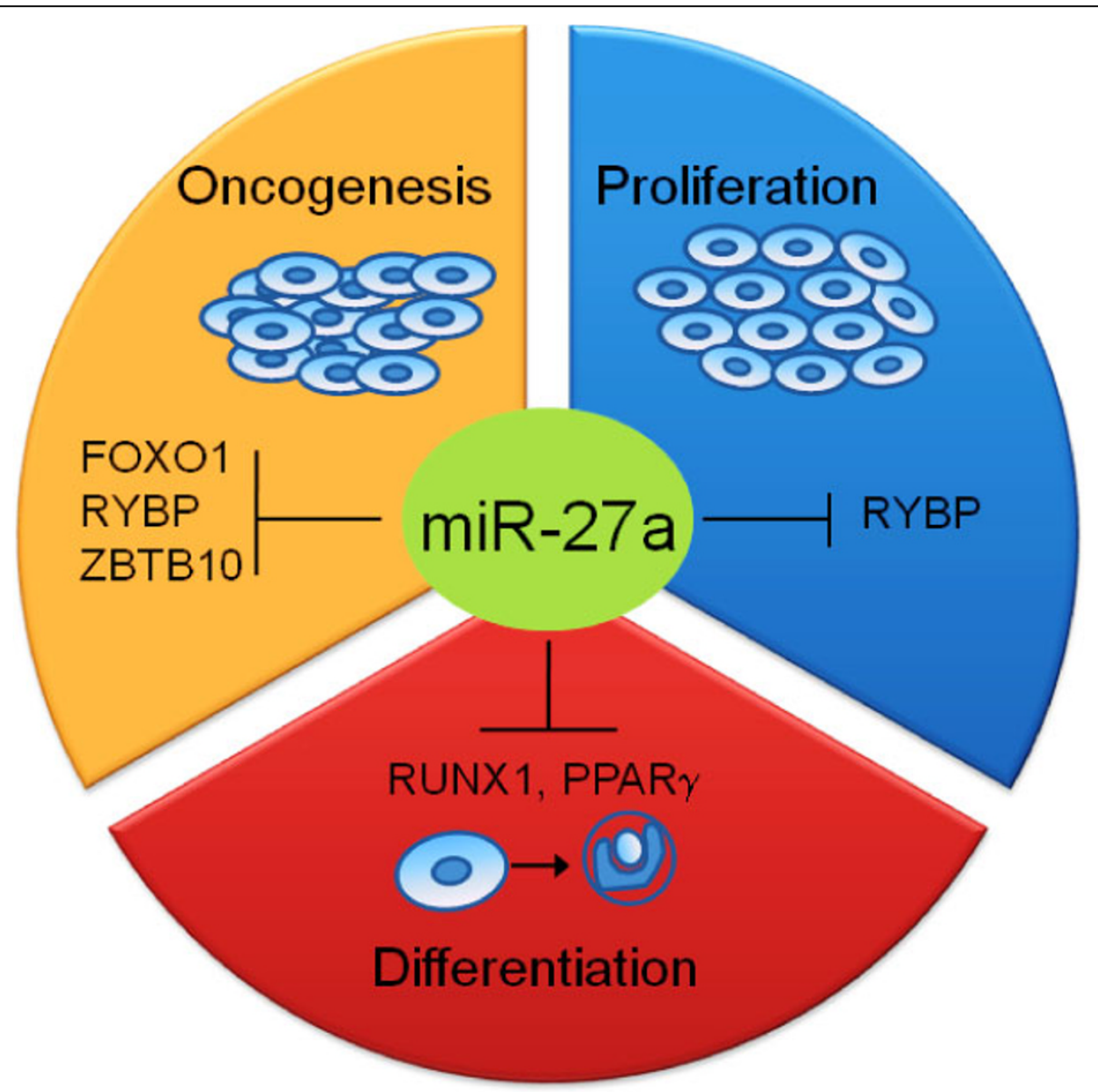

Figure 3 Importance of hsa-miR-27a in oncogenesis, proliferation and differentiation. miR-27a induces oncogenesis by negatively regulating FOXO1 (transcription factor that regulates genes involved in apoptosis and cell cycle progression), RYBP (pro-apoptotic gene) and ZBTB10 (repressor of Sp proteins which are known to cause proliferative and angiogenic phenotype in cancer cells), mediates differentiation by down regulating RUNX1 (regulator of haematopoesis) and PPAR $\gamma$ and also promotes proliferation by targeting RYBP (pro-apoptotic gene).

Interestingly, Eitan et al in 2009 observed high expression of hsa-mir-27a in a sub-group of patients with very poor prognosis [67].

miR-27a in osteoarthritis pathological process The effect of miR-27a on overall regulation of matrix metalloprotease-13 (MMP-13) and insulin-like growth factor binding protein (IGFBP), two genes involved in osteoarthritis (OA) pathophysiology adds another level of complexity to miR-27a mediated gene regulation. Tardif et al in their study showed that miR-27a indirectly decreases both matrix metalloprotease-13 (MMP-13) and the insulin-like growth factor binding protein (IGFBP) [68]. Since MMP-13 degrades a wide range of matrix components and IGFBP-5 plays an important storage role for anabolic factor IGF-1, this regulation by miR-27a could open up novel avenues in OA therapeutic strategies.

In addition to the regulatory role of miR-27a in diverse processes, miR-27a has also been associated with viral infections. It has been observed that both host and virus contain mechanisms to regulate miRNA expression and/or activity [26].

miR-27a in differentiation miR-27a has been identified as a negative regulator of adipocyte differentiation in a study by Kim et al in 2010 [69]. It has been observed that the expression of miR-27a decreases during adipogenesis while expression of peroxisome proliferators-activated receptor-gamma (PPAR $\gamma$ ) increases during adipogenesis. Lin et al in an independent study showed that miR-27a block the transcriptional induction of PPAR $\gamma$ and C/EBP $\alpha$ [70]. Since PPAR $\gamma$ has been implicated in the pathology of numerous diseases (including obesity, diabetes, atherosclerosis and cancer) and miR-27a has been found to suppress PPAR $\gamma$; it appears that miR27a could be a novel therapeutic target against metabolic complications associated with obesity as well as cancer.

In another study, Ben-Ami et al observed that miR$27 \mathrm{a}$ attenuates the expression of transcription factor 
RUNX1, a key regulator of hematopoiesis. In K562 cells, expression of RUNX1, a lineage-specific gene expression regulator has been found to increase during megakaryocyte differentiation. It seems that there exists a feedback loop mechanism between miR-27a and RUNX1 during megakaryopoiesis as the RUNX1 binding sites have been found upstream of miR-27a and the increase in miR-27a expression has been concomitantly found with the binding of RUNX1 to miR-27a [71].

miRNA 27a has also been found to play a critical role during osteogenesis. Schoolmeesters et al in their study in 2009 observed that grancalcin (GCA), a regulator of osteogenesis in human mesenchymal stem cells (hMSC) is a target of miR-27a [72]. It was also observed that expression of miR-27a decreases upon osteogeneic differentiation.

miR-27a regulates fat metabolism and cell proliferation Ji et al in 2009 observed that miR-27a along with miR-27b were up-regulated in activated Hepatic stellate cells (HSCs). Under normal conditions HSCs reside in the space of Disse, containing bunches of vitamin Ariching lipid droplets and upon activatation HSCs lose cytoplasmic lipid droplets and trans-differentiate to proliferative, fibrogenic myofibroblasts, and play an essential role in the formation of liver fibrosis. It was also observed by the authors that down-regulation of overexpressed miR-27a and 27b allowed activated HSCs to accumulate cytoplasmic lipid droplets leading to decreased HSCs proliferation. They also observed that the fatty acid metabolism and cell proliferation regulating properties of miR-27a and miR-27b maybe, at least partly mediated by affecting $R X R \alpha$ expression [73]. It has been documented that RXR $\alpha$ plays a central role in adipogenesis, probably as a heterodimeric partner for peroxisome proliferator-activated receptor. RXR $\alpha$ also suppresses DNA synthesis and causes cell growth arrest in a variety of cell types including HSCs.

\section{miR-24}

miR-24-2 is unique among miRNAs of this cluster since miR-24 can originate from two different genomic loci one localized on chromosome 19p13 encoding miR-23b, $-27 b$, and -24-1, and the other localized on chromosome 9q22 encoding miR-23a, -27a, and -24-2.

Since, mir-24-1 and miR-24-2 have the same mature sequence but different primary transcripts, it means that they have similar biological functions but both of them are differentially expressed and regulated. A number of targets of miR-24 have been validated and its role in various diseases have been studied (Fig. 4).

miR-24 in haematopoetic differentiation miR-24 is among many miRNAs which have been found to play a profound role in haematopoetic differentiation. Wang et al in 2008 reported that miR-24 targets human activin type I receptor ALK4 (hALK4) and modulates erythropoeisis. Activin in cooperation with erythropoietin plays an important role in differentiation of erythroid progenitors. Activin binds to type II activin receptor, leading to the recruitment, phosphorylation, and activation of type I activin receptor (ALK4, also known as ActRIB). The activated ALK4 phosphorylates SMAD2 and SMAD3, which, upon phosphorylation, form a heterocomplex with Co-SMAD (SMAD4), and the resulting SMAD complex binds to the promoter of the target genes, and regulates their expression. The authors show that miR-24 down-regulated hALK4 and attenuated the transcriptional responses of activin [74].

In a separate study, Lal et al in 2009 observed that miR-24 regulates the histone variant H2AFX, a key double-stranded break (DSB) repair protein during post mitotic differentiation of hematopoietic cell lines [16]. The reduction in miR-24 levels correlate with enhanced H2AFX mRNA and protein levels. Increased miR-24 levels have been found during differentiation while diminished miR-24 levels have been found in primary human blood cells. Moreover, it has also been observed that miR-24-mediated suppression of H2AFX renders cells hypersensitive to gamma-irradiation and genotoxic drugs.

miR-24 in tumorigenesis Both the miR-24 loci (9q and $19 \mathrm{p})$ are shown to be frequently altered in oral squamous cell carcinoma (OSCC). Recently, Lin et al (2010) found that miR-24 was up-regulated in OSCC tissues, plasma and OSCC cell lines in comparison to normals. The authors also observed that miR-24 might be contributing to the growth of OSCC cells by targeting p57 (KIP2), a member of the KIP (kinase inhibitory protein) family of CKI, a potential tumor suppressor gene [75].

Several reports in the literature show that miR-24 might function differently in different cells. miR-24 promotes proliferation of transforming growth factor $\beta$ treated hepatocellular carcinoma cells (HuH7) as well as A549 lung carcinoma cells and inhibits proliferation in HeLa cells [76]. miR-24 promotes proliferation by indirect suppression of CHEK1 (which participates in G2-M checkpoint), BRCA1 (that activates double-strand break repair), CDKN1B (cyclin D inhibitor, p27Kip1) and VHL (tumor suppressor gene). Previous study by Lal et al further strengthened the proliferative function of miR24 where they have shown that miR-24 directly suppresses CDK inhibitor p16INK4A which arrests cells in the G1 phase [77]. It is well known that over expression of Fas-associated factor-1 (FAF-1) stimulates apoptosis and down-regulation contributes to tumorogenesis. Qin et al showed that miR-24 can be a potential target for gene and drug therapy to treat hormone insensitive prostate cancer cells as they observed that increase of FAF-1 after miR-24 down-regulation induced significant apoptosis in DU-145, HGC-27, MGC-803 and HeLa 


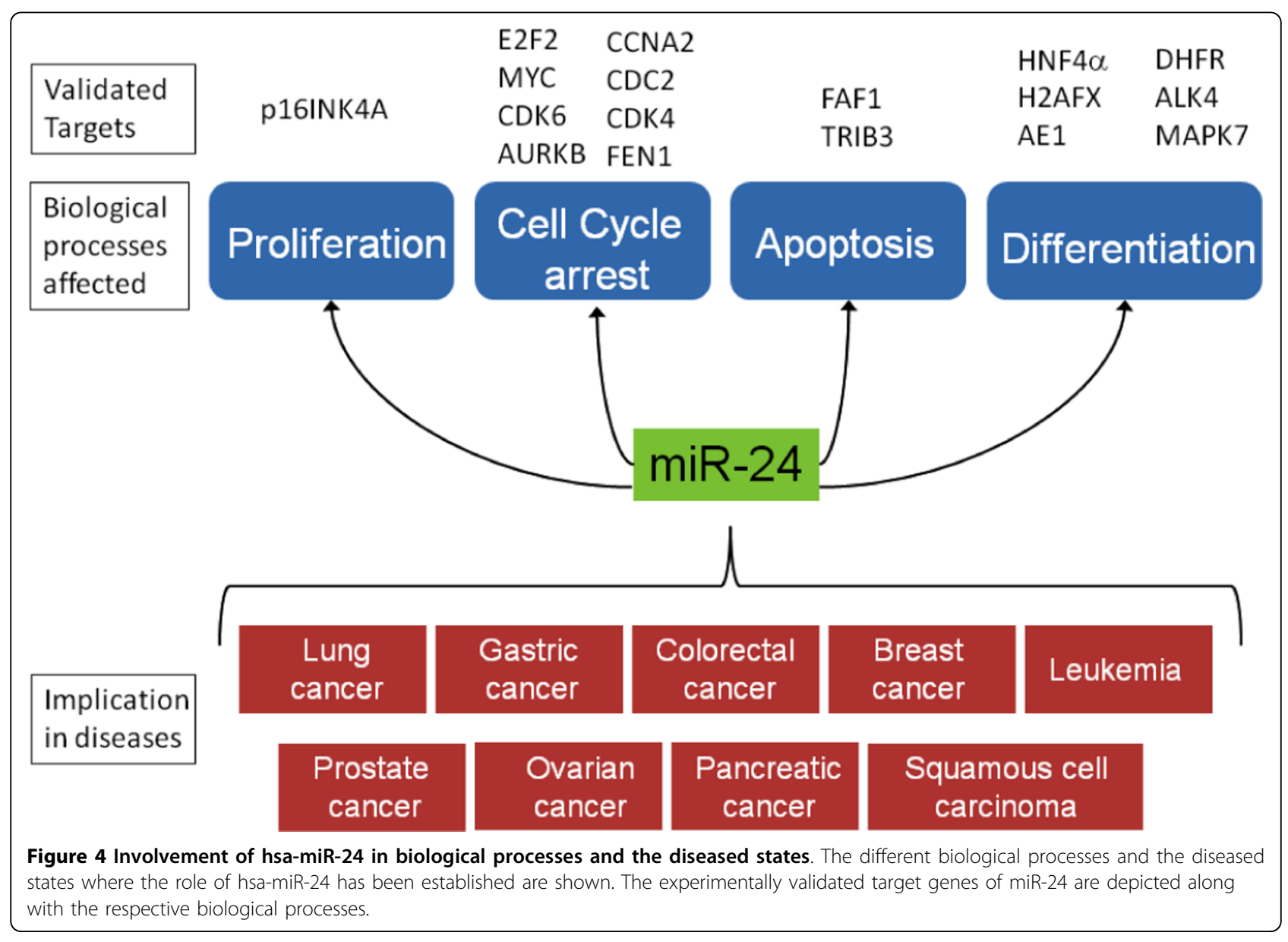

cells [78]. Also, the anti-apoptotic role played by miR-24 might aid in cellular proliferation.

Anti-proliferative activity of miR-24 can be attributed through the regulation of multiple targets of cell cycle. Lal et al showed that miR-24 suppresses several key genes that regulate cell-cycle progression like MYC and E2F2 and several genes downstream of E2F2 and MYC i.e., AURKB, CCNA2, CDK4, CDC2 and FEN1 [79]. Additionally, they have also shown that MCM4, MCM10, RRM2 and PCNA are indirectly down-regulated by miR-24. Moreover it was observed that in addition to HepG2 and K562 cells this anti-proliferative effect can also be seen in human diploid fibroblasts.

Another level of miR-24 regulation in cell cycle progression came to light when Takagi et al found that miR-24 down-regulates the expression of HNF4 $\alpha$, a transcription factor regulating endo/xenobiotic-metabolism [80]. The down-regulation of HNF4 $\alpha$ by miR-24 resulted in the decrease of various target genes such as cytochrome P450 7A1 and 8B1 as well as decrease of the $S$ phase population in HepG2 cells. They also observed that the levels of miR-24 increase in HepG2 cells when treated with PMA, a protein kinase C/ mitogen-activated protein kinase (PKC/MAPK) activator and $\mathrm{H}_{2} \mathrm{O}_{2}$, reactive oxygen species (ROS) generator. Since activation of PKC pathway induces cholestasis [81] and ROS pathway has a role in steato-hepatitis [82] and in both the diseases HNF $4 \alpha$ is down-regulated [83-85], they inferred that this could be because of induction of miR-24.

Another role of miR-24 where they contribute to tumorigenesis was shown by Mishra et al. They showed that miR-24 regulates expression of the dihydrofolate reductase (DHFR), a key enzyme in intracellular folate metabolism and target of methotrexate (MTX), an important chemotherapeutic agent widely used in the treatment of several malignancies [86]. It was observed that a miR-24 target site polymorphism in DHFR 3' UTR results in loss of miR-24-function and high DHFR levels in the cell imparts a growth advantage to immortalized cells and induces neoplastic transformation. Enough evidence is there to say that miR-24 is deregulated in human colorectal cancer tumors and a subset of tumors has reduced levels of miR-24. These results are consistent with the data reported by $\mathrm{Wu}$ et al [87]. Their experiments indicated reduced expression of miR- 
24 in gastric cancer cells. In their study they also observed that miR-24 is a key factor for the induction of anion exchanger-1 (AE1). Functional AE1 is an erythroid-specific integral membrane protein expressed on the surface of mature erythrocyte. Under normal conditions full length AE1 is silenced at protein level in other tissues and has been found to impact the differentiation of erythroid lineage cells. AE1 mediates the $\mathrm{Cl}^{-} / \mathrm{HCO}^{-}$ exchange across the plasma membrane, regulates intracellular $\mathrm{pH}$ and interacts with ankyrin, protein 4.1, spectrin which comprise the erythrocyte cytoskeleton. Increased expression of $\mathrm{AE} 1$ has been found in the cytoplasm in gastric and adenocarcinoma. AE1 interacts with another mir-24 target tumor suppressor p16 and sequesters p16 in the cytoplasm, thereby leading to loss of control of cell-cycle regulation and induction of gastric carcinogenesis. Transfection of a miR-24 into gastric cancer cells reduced the elevation of the AE1 protein, which resulted in return of AE1-sequestrated p16 to the nucleus, thereby inhibiting proliferation of the cells. The undetectable expression of AE1 in K562 cells suggested that miR-24 may take part in the tumorigenesis of erythroleukemia by arresting erythroid maturation through silencing of AE1 expression.

mir-24 emerged as a biomarker specific for Kaposi Sarcoma (KS) in a study done by O'Hara et al in 2009 to identify specific miRNAs that serve as biomarkers for tumor progression [88]. Apart from differentiation, proliferation and cell cycle regulation, miR-24 has also been found to be among the miRNAs which are Hodgkin lymphoma (HL) specific [89]. Recently, Liu et al in 2010 identified it as the differentially expressed miRNA involved in HCV entry, replication and propagation [90]. miR-24 in phenotypic plasticity Phenotypic plasticity is essential for vascular development and vascular remodeling after injury as well as vascular proliferative diseases like atherosclerosis, pulmonary arterial hypertension etc. In response to injury, vascular smooth muscle cells (vSMCs) undergo phenotypic modulation from quiescent contractile phenotype to a proliferative synthetic state. Transforming growth factor- $\beta$ (TGF $\beta$ ) and Bone morphogenetic protein (BMP) pathways stimulate contractile phenotype whereas PDGF (plateletderived growth factor)-signaling pathway promotes synthetic pathway. Recently Chan et al in 2010 observed that miR-24 is a key regulator of the crosstalk between the pro-contractile TGF $\beta / B M P$ signal and the prosynthetic PDGF signal. The authors observed that hat PDGF-BB induces miR-24, which in turn leads to downregulation of Tribbles-like protein-3 (TRIB3) [91]. Repression of TRIB3 coincides with reduced expression of SMAD proteins and decrease in BMP and TGF $\beta$ signaling, promoting a synthetic (proliferative) phenotype in vascular smooth-muscle-cell (vSMC) rather than quiescent (contractile) phenotype. Inhibition of miR-24 by antisense oligonuclotides abrogates the down-regulation of TRIB3 as well as pro-synthetic activity of the PDGF-signaling pathway.

\section{Biological relevance of miR-23a 27a 24-2 cluster as revealed by bioinformatic analysis}

The overall cellular functions and pathways affected by co-expressed miRNAs remains largely undiscovered due to lack of high throughput target validation methods and such studies mostly rely on computational analysis of potential mRNA targets. Hence, most of the research on miRNAs to date has focused on individualistic effects of a miRNA. However, there are still a few reports which suggest that the miRNAs in a miRNA cluster effectively cooperate by targeting the individual genes of the same pathway thus justifying their coexistence [22,92]. To reveal biological significance of miR-23a 27a 24-2 cluster, a list of predicted targets of miR-23a, miR-27a and miR-24 was made using the TargetScan program, miRNA target prediction software (Additional File 2) $[93,94]$. From this list, we discovered that although the three miRNAs of this cluster shared very few predicted mRNA targets (Table 2) but still all the three miRNAs were reported either up-regulated or down-regulated simultaneously in several pathological states (Table 1); thereby indicating a possible connection between their target mRNAs.

To evaluate the specific pathways or processes that are targeted by the miRNAs of this cluster, we used the list from TargetScan program to find enriched pathways by GeneCodis [95,96] and PANTHER analysis [97]. The PANTHER analysis revealed many signaling pathways as the enriched categories (Fig. 5, Additional File 3). In

Table $\mathbf{2}$ The common genes among the predicted target
genes of miRNAs of miR-23a 27a 24-2 cluster in
TargetScan
\begin{tabular}{ll} 
Gene & Definition \\
Name & \\
\hline ADAM19 & ADAM metallopeptidase domain 19 (meltrin beta) \\
\hline ADAMTS6 & $\begin{array}{l}\text { ADAM metallopeptidase with thrombospondin type } 1 \\
\text { motif, } 6\end{array}$ \\
\hline CSNK1G1 & Casein kinase 1, gamma 1 \\
\hline EBF3 & Early B-cell factor 3 \\
\hline KPNA3 & Karyopherin alpha 3 (importin alpha 4) \\
\hline LIMK2 & LIM domain kinase 2 \\
\hline NCOA1 & Nuclear receptor coactivator 1 \\
\hline NLK & Nemo-like kinase \\
\hline PLEKHH2 & $\begin{array}{l}\text { Pleckstrin homology domain containing, family H (with } \\
\text { MyTH4 domain) member } 2\end{array}$ \\
\hline RAP1B & RAP1B, member of RAS oncogene family \\
\hline SOCS6 & Suppressor of cytokine signaling 6 \\
\hline
\end{tabular}




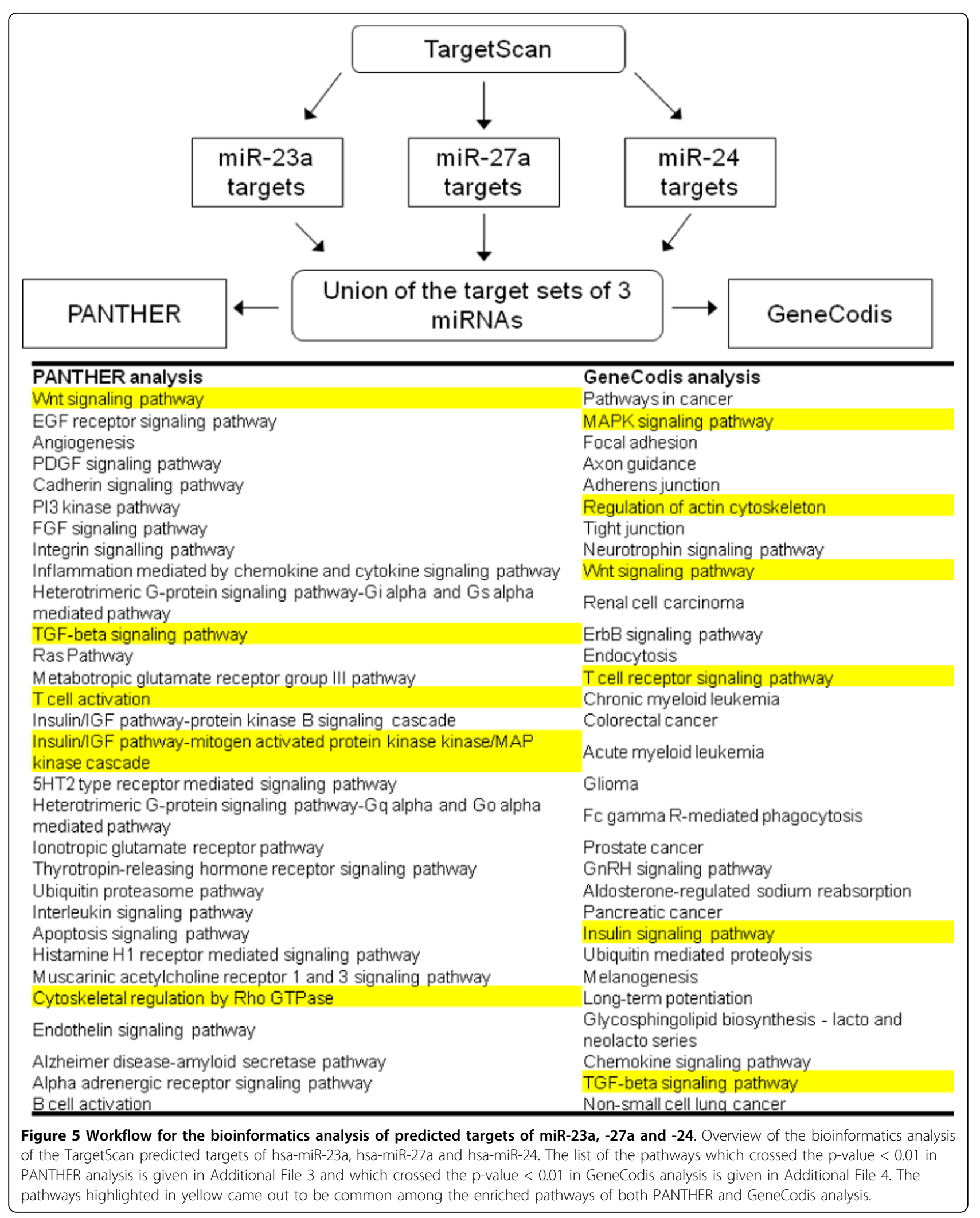




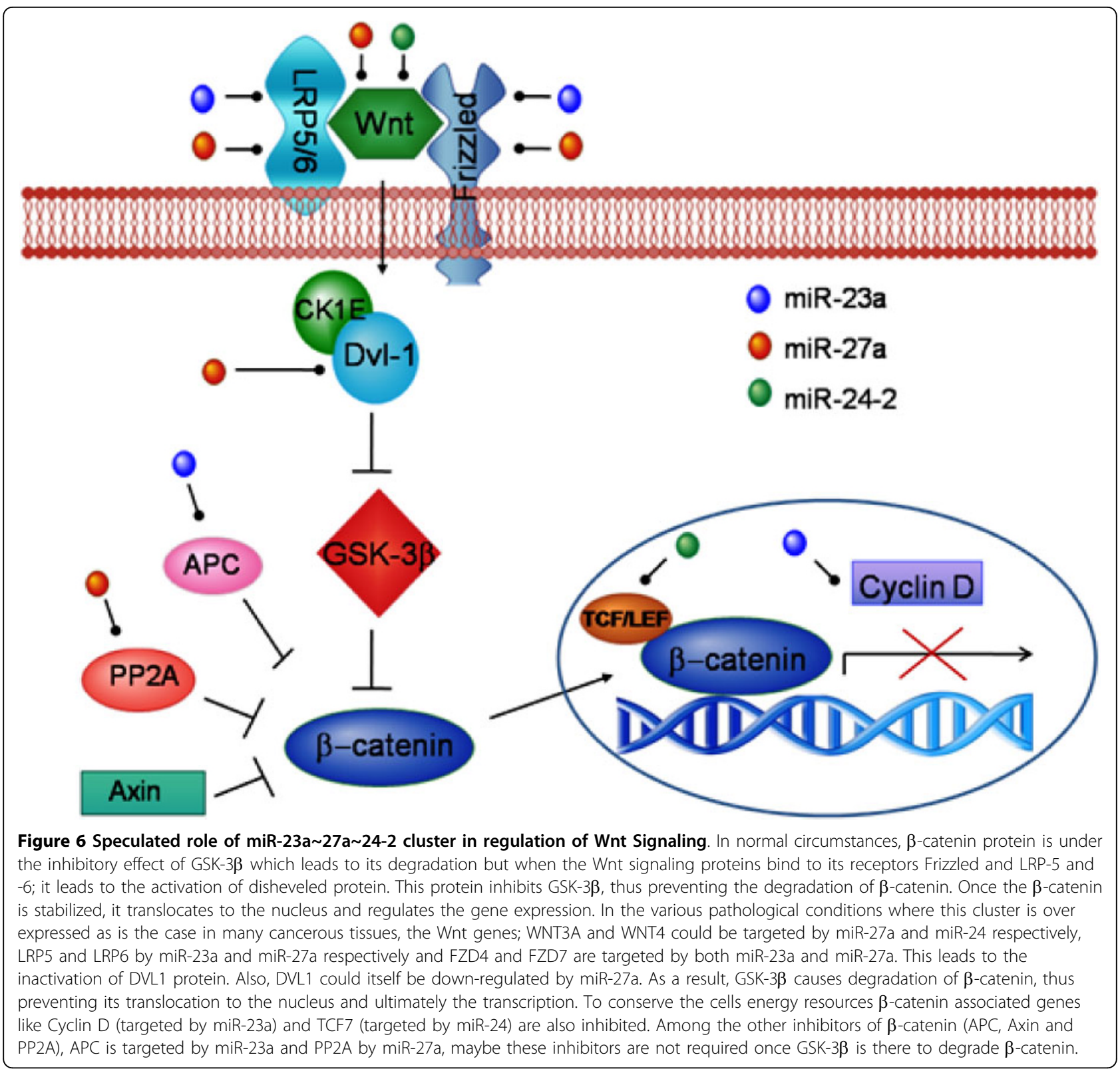

GeneCodis analysis, in addition to signaling pathways, several diseases viz., colorectal cancer, pancreatic cancer, renal carcinoma, chronic myeloid leukemia, acute myeloid leukemia and glioma are among the statistically significant enriched categories (Fig. 5, Additional File 4). It is noteworthy that the differential expression of miR23a, miR-24-2 and miR-27a has already been reported in many of these diseased states (Table 1).

Interestingly, we observed that the Wnt, MAPK, TGF$\beta$ pathways, Insulin signaling, $\mathrm{T}$ cell receptor signaling and cytoskeletal regulation were the enriched categories (p-value $<0.01$ ) in both PANTHER and GeneCodis analysis. There are a few reports which have talked about the involvement of miRNAs of this cluster in both
MAPK signaling $[98,99]$ and TGF- $\beta$ signaling $[13,91,100]$. Since we got Wnt signaling as the enriched pathway in the similar bioinformatic analysis for all three miRNAs separately also (data not shown); we tried to illustrate the cooperativity of miRNAs of this cluster in regulating Wnt signaling (Fig. 6).

Wnt- $\beta$-catenin signaling controls critical events in development, and its dysregulation leads to cancers and developmental disorders. In normal circumstances, $\beta$ catenin protein is under the inhibitory effect of GSK-3 $\beta$ which leads to its degradation but when the Wnt signaling proteins bind to its receptors Frizzled and LRP-5 and -6 ; it leads to the activation of disheveled protein. This protein is an inhibitor of GSK-3 $\beta$, thus preventing 
the degradation of $\beta$-catenin. The stable $\beta$-catenin moves to the nucleus and regulates the gene expression. As shown in Fig. 6 the various genes involved in Wnt signaling pathway may be targeted by the miRNAs of the miR-23a 27a 24-2 cluster. If that is the case then this cluster would lead to degradation of $\beta$-catenin resulting in blockage of transcription. It is remarkable that a few genes of the Wnt pathway are targeted by more than one miRNA thus indicating strong association among miRNAs and their stringent regulation of the pathway.

This in-silico analysis implies that the miRNAs present in this cluster could complement each other in regulating a certain pathway. Although, the targets used for this study are bioinformatically predicted and not validated, Further characterization of the functional interaction between Wnt signaling/ $\beta$-catenin and miRNAs of miR-23a 27a 24-2 cluster will be required to clarify the role of miR-23a 27a 24-2 cluster in regulating Wnt signaling.

In many studies, individual effect of a miRNA may appear to be small but when they cooperate, the effect can be of significant proportions. The cooperativity among miRNAs is thus an interesting area of study and can change our perception of how we look at the miRNA mediated gene regulation.

\section{Conclusions}

miRNAs are complex molecules and since they target a host of genes, their functions in a cell type are highly dependent on the repertoire of the genes present in that cell. In one type of cell, a miRNA can act as an apoptotic factor and in another the same miRNA can act as proliferation promoting factor. The fact that the miRNAs can be under the control of other genes further adds to their complexity. For instance, Kong et al recently reported that the miR-23a 27a 24-2 transcript is a downstream target of PU.1 and this cluster is the causal factor behind PU.1 promoting the myeloid differentiation over lymphoid differentiation [18]. As a result, it is highly improbable to characterize the functions of miRNAs and annotate them as yet. So far, most of the research in miRNA has been focused on the role of individual miRNA on regulating a particular gene. But, it is quite imperative to study the cooperative effects of miRNAs on regulating a cellular pathway or deciding the fate of a cell. This insight will give us a holistic picture of the miRNA regulation in the cell. The miRNAs present together in a cluster seems the most obvious subject to decipher the cooperative effects of miRNAs. There are a few reports in the literature which talk about cooperation among miRNAs in clusters. Yuan et al. have investigated the extent of coordination of miRNAs in regulating protein-protein interaction network
[22]. They have shown that clustered miRNAs jointly regulate proteins which lie in close proximity in the interaction network. Kim et al have added a new dimension to this by reporting that separate clusters can also be co-expressed and have related activities [92]. Herein, we have discussed the individual functions of miRNAs of miR-23a 27a 24-2 cluster that have been experimentally validated and looked at their role in cooperation with each other. For studying the cooperative effects of miRNA in the cluster, we obtained the list of predicted targets of miR-23a, miR-27a, and miR-24 from TargetScan and used them for discovering enriched pathways. The analysis revealed the various enriched pathways and diseases, thus justifying their occurrence together in a single transcript and under the control of a single promoter. Although, this bioinformatic analysis needs to be validated experimentally, such a study would go a long way in the understanding of miRNA clusters. The study of miRNAs in coordination with each other is a must if we want to exploit miRNAs for therapeutic purposes.

\section{Additional material}

Additional file 1: Presence/Absence of miRNAs of the two paralogous clusters in vertebrates. The presence/absence of miRNAs $(-23 a, 27 a,-24,-23 b,-27 b)$ in vertebrates as indicated in miRBase is represented in a table.

Additional file 2: Predicted targets of hsa-miR-23a, hsa-miR-27a and hsa-miR-24 by TargetScan. This file contains the list of targets of hsamiR-23a, hsa-miR-27a and hsa-miR-24 as predicted by the TargetScan. The union of the targets of these three miRNAs is used for bioinformatic analysis as reported in the manuscript.

Additional file 3: Enriched pathways from PANTHER analysis. This file contains the list of enriched pathways obtained using PANTHER analysis that satisfies the criteria of p-value $<0.01$.

Additional file 4: Enriched pathways from GeneCodis analysis. This file contains the list of enriched pathways obtained using GeneCodis analysis that satisfies the criteria of $p$-value $<0.01$.

\section{Acknowledgements}

The authors acknowledge the Council of Scientific and Industrial Research (CSIR) funded project 'Comparative genomics and biology of non-coding RNA in the human Genome' (NWP0036). RC was supported with CSIR-Senior Research Fellowship.

\section{Authors' contributions}

RC and NS conceived the study. The survey of the literature and the inferences were made by RC, RD and NS. The bioinformatics analysis was carried out by RC. The manuscript was drafted by all the authors. All the authors have read and approved the final manuscript.

\section{Competing interests}

The authors declare that they have no competing interests.

Received: 2 June 2010 Accepted: 3 September 2010

Published: 3 September 2010

\section{References}

1. Lee $Y$, Jeon K, Lee JT, Kim S, Kim VN: MicroRNA maturation: stepwise processing and subcellular localization. EMBO J 2002, 21:4663-4670. 
2. Zeng $Y$, Cullen BR: Sequence requirements for micro RNA processing and function in human cells. RNA 2003, 9:112-123.

3. Yi R, Qin Y, Macara IG, Cullen BR: Exportin-5 mediates the nuclear export of pre-microRNAs and short hairpin RNAs. Genes Dev 2003, 17:3011-3016.

4. Lund E, Guttinger S, Calado A, Dahlberg JE, Kutay U: Nuclear export of microRNA precursors. Science 2004, 303:95-98.

5. Hutvagner G, McLachlan J, Pasquinelli AE, Balint E, Tuschl T, Zamore PD: A cellular function for the RNA-interference enzyme Dicer in the maturation of the let-7 small temporal RNA. Science 2001, 293:834-838.

6. Lee Y, Ahn C, Han J, Choi H, Kim J, Yim J, Lee J, Provost P, Radmark O, Kim S, Kim VN: The nuclear RNase III Drosha initiates microRNA processing. Nature 2003, 425:415-419.

7. Lee RC, Feinbaum RL, Ambros V: The C. elegans heterochronic gene lin-4 encodes small RNAs with antisense complementarity to lin-14. Cell 1993, 75:843-854.

8. Griffiths-Jones S, Saini HK, van Dongen S, Enright AJ: miRBase: tools for microRNA genomics. Nucleic Acids Res 2008, 36:D154-158.

9. Altuvia $Y$, Landgraf $P$, Lithwick $G$, Elefant N, Pfeffer S, Aravin A, Brownstein MJ, Tuschl T, Margalit H: Clustering and conservation patterns of human microRNAs. Nucleic Acids Res 2005, 33:2697-2706.

10. Chan JA, Krichevsky AM, Kosik KS: MicroRNA-21 is an antiapoptotic factor in human glioblastoma cells. Cancer Res 2005, 65:6029-6033.

11. He L, Thomson JM, Hemann MT, Hernando-Monge E, Mu D, Goodson S, Powers S, Cordon-Cardo C, Lowe SW, Hannon GJ, Hammond SM: A microRNA polycistron as a potential human oncogene. Nature 2005, 435:828-833.

12. Omoto S, Ito M, Tsutsumi Y, Ichikawa Y, Okuyama H, Brisibe EA, Saksena NK, Fujii YR: HIV-1 nef suppression by virally encoded microRNA. Retrovirology 2004, 1:44.

13. Huang S, He X, Ding J, Liang L, Zhao Y, Zhang Z, Yao X, Pan Z, Zhang P, $\mathrm{Li} J$, et al: Upregulation of miR-23a approximately $27 \mathrm{a}$ approximately 24 decreases transforming growth factor-beta-induced tumor-suppressive activities in human hepatocellular carcinoma cells. Int J Cancer 2008, 123:972-978.

14. Chhabra R, Adlakha YK, Hariharan M, Scaria V, Saini N: Upregulation of miR23a-27a-24-2 cluster induces caspase-dependent and -independent apoptosis in human embryonic kidney cells. PLoS One 2009, 4:e5848

15. Mertens-Talcott SU, Chintharlapalli S, Li X, Safe S: The oncogenic microRNA-27a targets genes that regulate specificity protein transcription factors and the G2-M checkpoint in MDA-MB-231 breast cancer cells. Cancer Res 2007, 67:11001-11011.

16. Lal A, Pan Y, Navarro F, Dykxhoorn DM, Moreau L, Meire E, Bentwich Z, Lieberman J, Chowdhury D: miR-24-mediated downregulation of H2AX suppresses DNA repair in terminally differentiated blood cells. Nat Struct Mol Biol 2009, 16:492-498.

17. Lin Z, Murtaza I, Wang K, Jiao J, Gao J, Li PF: miR-23a functions downstream of NFATC3 to regulate cardiac hypertrophy. Proc Natl Acad Sci USA 2009, 106:12103-12108.

18. Kong KY, Owens KS, Rogers JH, Mullenix J, Velu CS, Grimes HL, Dahl R: MIR23A microRNA cluster inhibits B-cell development. Exp Hematol 2010, 38(8):629-640.e1, Epub 2010 May 5.

19. Yu J, Wang F, Yang GH, Wang FL, Ma YN, Du ZW, Zhang JW: Human microRNA clusters: genomic organization and expression profile in leukemia cell lines. Biochem Biophys Res Commun 2006, 349:59-68.

20. Andrea Tanzer MR, Hertel Jana, Bermudez-Santana Isabel Clara, Gorodkin Jan, Hofacker LIvo, Stadler FPeter: Evolutionary Genomics of microRNAs and Their Relatives. In Evolutionary Genomics and Systems Biology. Edited by: Caetano-Anolles G. Hoboken: Wiley-Blackwell; 2010:295-327.

21. Tanzer A, Stadler PF: Molecular evolution of a microRNA cluster. J Mol Biol 2004, 339:327-335

22. Yuan X, Liu C, Yang P, He S, Liao Q, Kang S, Zhao Y: Clustered microRNAs' coordination in regulating protein-protein interaction network. BMC Syst Biol 2009, 3:65.

23. Lee Y, Kim M, Han J, Yeom KH, Lee S, Baek SH, Kim VN: MicroRNA genes are transcribed by RNA polymerase II. EMBO I 2004, 23:4051-4060.

24. Smale ST, Kadonaga JT: The RNA polymerase II core promoter. Annu Rev Biochem 2003, 72:449-479.

25. Saini HK, Griffiths-Jones S, Enright AJ: Genomic analysis of human microRNA transcripts. Proc Natl Acad Sci USA 2007, 104:17719-17724.
26. Buck AH, Perot J, Chisholm MA, Kumar DS, Tuddenham L, Cognat V Marcinowski L, Dolken L, Pfeffer S: Post-transcriptional regulation of miR27 in murine cytomegalovirus infection. RNA 2010, 16:307-315.

27. Lee JY, Kim S, Hwang do W, Jeong JM, Chung JK, Lee MC, Lee DS: Development of a dual-luciferase reporter system for in vivo visualization of MicroRNA biogenesis and posttranscriptional regulation. J Nucl Med 2008, 49:285-294.

28. Mi S, Lu J, Sun M, Li Z, Zhang H, Neilly MB, Wang Y, Qian Z, Jin J, Zhang Y, et al: MicroRNA expression signatures accurately discriminate acute lymphoblastic leukemia from acute myeloid leukemia. Proc Natl Acad Sci USA 2007, 104:19971-19976.

29. Lee EJ, Gusev Y, Jiang J, Nuovo GJ, Lerner MR, Frankel WL, Morgan DL, Postier RG, Brackett DJ, Schmittgen TD: Expression profiling identifies microRNA signature in pancreatic cancer. Int I Cancer 2007, 120:1046-1054

30. Fulci V, Chiaretti S, Goldoni M, Azzalin G, Carucci N, Tavolaro S, Castellano L, Magrelli A, Citarella F, Messina M, et al: Quantitative technologies establish a novel microRNA profile of chronic lymphocytic leukemia. Blood 2007, 109:4944-4951.

31. Mattie MD, Benz CC, Bowers J, Sensinger K, Wong L, Scott GK, Fedele V, Ginzinger D, Getts R, Haqq C: Optimized high-throughput microRNA expression profiling provides novel biomarker assessment of clinical prostate and breast cancer biopsies. Mol Cancer 2006, 5:24.

32. Liu T, Tang H, Lang Y, Liu M, Li X: MicroRNA-27a functions as an oncogene in gastric adenocarcinoma by targeting prohibitin. Cancer Lett 2009, 273:233-242

33. Volinia $S$, Calin GA, Liu CG, Ambs S, Cimmino A, Petrocca F, Visone R, lorio M, Roldo C, Ferracin M, et al: A microRNA expression signature of human solid tumors defines cancer gene targets. Proc Natl Acad Sci USA 2006, 103:2257-2261

34. Meng F, Henson R, Lang M, Wehbe $H$, Maheshwari S, Mendell JT, Jiang J, Schmittgen TD, Patel T: Involvement of human micro-RNA in growth and response to chemotherapy in human cholangiocarcinoma cell lines. Gastroenterology 2006, 130:2113-2129.

35. Rogler CE, Levoci L, Ader T, Massimi A, Tchaikovskaya T, Norel R, Rogler LE: MicroRNA-23b cluster microRNAs regulate transforming growth factorbeta/bone morphogenetic protein signaling and liver stem cell differentiation by targeting Smads. Hepatology 2009, 50:575-584.

36. Baek D, Villen J, Shin C, Camargo FD, Gygi SP, Bartel DP: The impact of microRNAs on protein output. Nature 2008, 455:64-71.

37. Selbach M, Schwanhausser B, Thierfelder N, Fang Z, Khanin R, Rajewsky N: Widespread changes in protein synthesis induced by microRNAs. Nature 2008, 455:58-63.

38. Massague J, Chen YG: Controlling TGF-beta signaling. Genes Dev 2000, 14:627-644.

39. Cameron JE, Fewell C, Yin Q, McBride J, Wang X, Lin Z, Flemington EK: Epstein-Barr virus growth/latency III program alters cellular microRNA expression. Virology 2008, 382:257-266.

40. Gao P, Tchernyshyov I, Chang TC, Lee YS, Kita K, Ochi T, Zeller Kl, De Marzo AM, Van Eyk JE, Mendell JT, Dang CV: c-Myc suppression of miR23a/b enhances mitochondrial glutaminase expression and glutamine metabolism. Nature 2009, 458:762-765.

41. Saumet A, Vetter G, Bouttier M, Portales-Casamar E, Wasserman WW, Maurin T, Mari B, Barbry P, Vallar L, Friederich E, et al: Transcriptional repression of microRNA genes by PML-RARA increases expression of key cancer proteins in acute promyelocytic leukemia. Blood 2009, 113:412-421

42. Gottardo F, Liu CG, Ferracin M, Calin GA, Fassan M, Bassi P, Sevignani C, Byrne D, Negrini M, Pagano F, et al: Micro-RNA profiling in kidney and bladder cancers. Urol Oncol 2007, 25:387-392.

43. Palmieri A, Pezzetti F, Avantaggiato A, Lo Muzio L, Scarano A, Rubini C, Guerzoni L, Arlotti M, Ventorre D, Carinci F: Titanium acts on osteoblast translational process. J Oral Implantol 2008, 34:190-195.

44. Larsson E, Fredlund Fuchs P, Heldin J, Barkefors I, Bondjers C, Genove G, Arrondel C, Gerwins P, Kurschat C, Schermer B, et al: Discovery of microvascular miRNAs using public gene expression data: miR-145 is expressed in pericytes and is a regulator of Fli1. Genome Med 2009, 1:108.

45. Poliseno L, Tuccoli A, Mariani L, Evangelista M, Citti L, Woods K, Mercatanti A, Hammond S, Rainaldi G: MicroRNAs modulate the angiogenic properties of HUVECs. Blood 2006, 108:3068-3071. 
46. Frey N, Olson EN: Cardiac hypertrophy: the good, the bad, and the ugly. Annu Rev Physiol 2003, 65:45-79.

47. Hunter JJ, Chien KR: Signaling pathways for cardiac hypertrophy and failure. N Engl J Med 1999, 341:1276-1283

48. Wada S, Kato Y, Okutsu M, Miyaki S, Suzuki K, Asahara H, Ushida T, Akimoto T: miR-23a attenuates skeletal muscle atrophy by targeting MAFbx/atrogin-1 and MuRF1. Journal of Physiological Sciences 2009, 59:216-216.

49. Wang X, Tang S, Le SY, Lu R, Rader JS, Meyers C, Zheng ZM: Aberrant expression of oncogenic and tumor-suppressive microRNAs in cervical cancer is required for cancer cell growth. PLoS One 2008, 3:e2557.

50. Guttilla IK, White BA: Coordinate regulation of FOXO1 by miR-27a, miR96, and miR-182 in breast cancer cells. J Biol Chem 2009, 284:23204-23216.

51. Belair C, Darfeuille F, Staedel C: Helicobacter pylori and gastric cancer: possible role of microRNAs in this intimate relationship. Clin Microbiol Infect 2009, 15:806-812.

52. Abdelrahim M, Smith R, Burghardt R, Safe S: Role of Sp proteins in regulation of vascular endothelial growth factor expression and proliferation of pancreatic cancer cells. Cancer Res 2004, 64:6740-6749.

53. Higgins KJ, Abdelrahim M, Liu S, Yoon K, Safe S: Regulation of vascular endothelial growth factor receptor-2 expression in pancreatic cancer cells by Sp proteins. Biochem Biophys Res Commun 2006, 345:292-301.

54. Abdelrahim M, Baker CH, Abbruzzese JL, Sheikh-Hamad D, Liu S, Cho SD, Yoon K, Safe S: Regulation of vascular endothelial growth factor receptor-1 expression by specificity proteins 1,3 , and 4 in pancreatic cancer cells. Cancer Res 2007, 67:3286-3294.

55. Wu J, Ling X, Pan D, Apontes P, Song L, Liang P, Altieri DC, Beerman T, Li F: Molecular mechanism of inhibition of survivin transcription by the GCrich sequence-selective DNA binding antitumor agent, hedamycin: evidence of survivin down-regulation associated with drug sensitivity. $J$ Biol Chem 2005, 280:9745-9751

56. Scott GK, Mattie MD, Berger CE, Benz SC, Benz CC: Rapid alteration of microRNA levels by histone deacetylase inhibition. Cancer Res 2006, 66:1277-1281.

57. Booher RN, Holman PS, Fattaey A: Human Myt1 is a cell cycle-regulated kinase that inhibits Cdc2 but not Cdk2 activity. J Biol Chem 1997, 272:22300-22306.

58. Parker LL, Piwnica-Worms H: Inactivation of the $\mathrm{p} 34 \mathrm{cdc}$-cyclin B complex by the human WEE1 tyrosine kinase. Science 1992, 257:1955-1957.

59. Liu F, Stanton JJ, Wu Z, Piwnica-Worms H: The human Myt1 kinase preferentially phosphorylates $\mathrm{Cdc} 2$ on threonine 14 and localizes to the endoplasmic reticulum and Golgi complex. Mol Cell Biol 1997, 17:571-583.

60. Chintharlapalli S, Papineni S, Abdelrahim M, Abudayyeh A, Jutooru I, Chadalapaka G, Wu F, Mertens-Talcott S, Vanderlaag K, Cho SD, et al: Oncogenic microRNA-27a is a target for anticancer agent methyl 2cyano-3,11-dioxo-18beta-olean-1,12-dien-30-oate in colon cancer cells. Int J Cancer 2009, 125:1965-1974.

61. Zhu H, Wu H, Liu X, Evans BR, Medina DJ, Liu CG, Yang JM: Role of MicroRNA miR-27a and miR-451 in the regulation of MDR1/Pglycoprotein expression in human cancer cells. Biochem Pharmacol 2008, 76:582-588.

62. Zhang H, Li M, Han Y, Hong L, Gong T, Sun L, Zheng X: Down-Regulation of miR-27a Might Reverse Multidrug Resistance of Esophageal Squamous Cell Carcinoma. Dig Dis Sci 2010, 55(9):2545-51, Epub 2009 Dec 4.

63. Sun Q, Cong R, Yan H, Gu H, Zeng Y, Liu N, Chen J, Wang B: Genistein inhibits growth of human uveal melanoma cells and affects microRNA27a and target gene expression. Oncol Rep 2009, 22:563-567.

64. van Jaarsveld MT, Helleman J, Berns EM, Wiemer EA: MicroRNAs in ovarian cancer biology and therapy resistance. Int I Biochem Cell Biol 2010, 42(8):1282-90, Epub 2010 Jan 18.

65. Yang $R$, Schlehe B, Hemminki K, Sutter $C$, Bugert $P$, Wappenschmidt B, Volkmann J, Varon R, Weber BH, Niederacher D, et al: A genetic variant in the pre-miR-27a oncogene is associated with a reduced familial breast cancer risk. Breast Cancer Res Treat 2010, 121(3):693-702, Epub 2009 Nov 18.

66. Arisawa T, Tahara T, Shibata T, Nagasaka M, Nakamura M, Kamiya Y, Fujita H, Hasegawa S, Takagi T, Wang FY, et al: A polymorphism of microRNA 27a genome region is associated with the development of gastric mucosal atrophy in Japanese male subjects. Dig Dis Sci 2007, 52:1691-1697.
67. Eitan R, Kushnir M, Lithwick-Yanai G, David MB, Hoshen M, Glezerman M, Hod M, Sabah G, Rosenwald S, Levavi H: Tumor microRNA expression patterns associated with resistance to platinum based chemotherapy and survival in ovarian cancer patients. Gynecol Oncol 2009, 114:253-259.

68. Tardif G, Hum D, Pelletier JP, Duval N, Martel-Pelletier J: Regulation of the IGFBP-5 and MMP-13 genes by the microRNAs miR-140 and miR-27a in human osteoarthritic chondrocytes. BMC Musculoskelet Disord 2009, 10:148.

69. Kim SY, Kim AY, Lee HW, Son YH, Lee GY, Lee JW, Lee YS, Kim JB: miR-27a is a negative regulator of adipocyte differentiation via suppressing PPARgamma expression. Biochem Biophys Res Commun 2010, 392:323-328.

70. Lin Q, Gao ZG, Alarcon RM, Ye JP, Yun Z: A role of miR-27 in the regulation of adipogenesis. Febs Journal 2009, 276:2348-2358.

71. Ben-Ami O, Pencovich N, Lotem J, Levanon D, Groner Y: A regulatory interplay between miR-27a and Runx1 during megakaryopoiesis. Proc Natl Acad Sci USA 2009, 106:238-243.

72. Schoolmeesters A, Eklund T, Leake D, Vermeulen A, Smith Q, Force Aldred $S$, Fedorov $Y$ : Functional profiling reveals critical role for miRNA in differentiation of human mesenchymal stem cells. PLoS One 2009, 4: e5605.

73. Ji J, Zhang J, Huang G, Qian J, Wang X, Mei S: Over-expressed microRNA$27 \mathrm{a}$ and $27 \mathrm{~b}$ influence fat accumulation and cell proliferation during rat hepatic stellate cell activation. FEBS Lett 2009, 583:759-766.

74. Wang Q, Huang Z, Xue H, Jin C, Ju XL, Han JD, Chen YG: MicroRNA miR-24 inhibits erythropoiesis by targeting activin type I receptor ALK4. Blood 2008, 111:588-595.

75. Lin SC, Liu CJ, Lin JA, Chiang WF, Hung PS, Chang KW: miR-24 upregulation in oral carcinoma: positive association from clinical and in vitro analysis. Oral Oncol 2010, 46:204-208.

76. Cheng AM, Byrom MW, Shelton J, Ford LP: Antisense inhibition of human miRNAs and indications for an involvement of miRNA in cell growth and apoptosis. Nucleic Acids Res 2005, 33:1290-1297.

77. Lal A, Kim HH, Abdelmohsen K, Kuwano Y, Pullmann R Jr, Srikantan S, Subrahmanyam R, Martindale JL, Yang X, Ahmed F, et al: p16(INK4a) translation suppressed by miR-24. PLoS One 2008, 3:e1864.

78. Qin W, Shi Y, Zhao B, Yao C, Jin L, Ma J, Jin Y: miR-24 regulates apoptosis by targeting the open reading frame (ORF) region of FAF1 in cancer cells. PLoS One 2010, 5:e9429.

79. Lal A, Navarro F, Maher CA, Maliszewski LE, Yan N, O'Day E, Chowdhury D, Dykxhoorn DM, Tsai $P$, Hofmann O, et al: miR-24 Inhibits cell proliferation by targeting E2F2, MYC, and other cell-cycle genes via binding to "seedless" 3'UTR microRNA recognition elements. Mol Cell 2009, 35:610-625.

80. Takagi S, Nakajima M, Kida K, Yamaura Y, Fukami T, Yokoi T: MicroRNAs regulate human hepatocyte nuclear factor 4alpha, modulating the expression of metabolic enzymes and cell cycle. J Biol Chem 2010, 285:4415-4422.

81. Kubitz R, Saha N, Kuhlkamp T, Dutta S, vom Dahl S, Wettstein M, Haussinger D: Ca2+-dependent protein kinase $C$ isoforms induce cholestasis in rat liver. J Biol Chem 2004, 279:10323-10330.

82. Day CP: Non-alcoholic steatohepatitis (NASH): where are we now and where are we going? Gut 2002, 50:585-588

83. Yue HY, Yin C, Hou JL, Zeng $X$, Chen YX, Zhong W, Hu PF, Deng $X$, Tan $Y X$, Zhang JP, et al: Hepatocyte nuclear factor 4alpha attenuates hepatic fibrosis in rats. Gut 2010, 59:236-246.

84. Xie X, Liao H, Dang H, Pang W, Guan Y, Wang X, Shyy JY, Zhu Y, Sladek FM: Down-regulation of hepatic HNF4alpha gene expression during hyperinsulinemia via SREBPs. Mol Endocrinol 2009, 23:434-443.

85. Geier A, Zollner G, Dietrich CG, Wagner M, Fickert P, Denk H, van Rooijen N, Matern S, Gartung C, Trauner M: Cytokine-independent repression of rodent Ntcp in obstructive cholestasis. Hepatology 2005, 41:470-477.

86. Mishra PJ, Humeniuk R, Longo-Sorbello GS, Banerjee D, Bertino JR: A miR24 microRNA binding-site polymorphism in dihydrofolate reductase gene leads to methotrexate resistance. Proc Natl Acad Sci USA 2007, 104:13513-13518.

87. Wu J, Zhang YC, Suo WH, Liu XB, Shen WW, Tian H, Fu GH: Induction of anion exchanger- 1 translation and its opposite roles in the carcinogenesis of gastric cancer cells and differentiation of K562 cells. Oncogene 2010, 29:1987-1996.

88. O'Hara AJ, Chugh P, Wang L, Netto EM, Luz E, Harrington WJ, Dezube BJ, Damania $B$, Dittmer DP: Pre-micro RNA signatures delineate stages of 
endothelial cell transformation in Kaposi sarcoma. PLoS Pathog 2009, 5: e1000389.

89. Gibcus JH, Tan LP, Harms G, Schakel RN, de Jong D, Blokzijl T, Moller P, Poppema $S$, Kroesen BJ, van den Berg A: Hodgkin lymphoma cell lines are characterized by a specific miRNA expression profile. Neoplasia 2009, 11:167-176.

90. Liu X, Wang T, Wakita T, Yang W: Systematic identification of microRNA and messenger RNA profiles in hepatitis $C$ virus-infected human hepatoma cells. Virology 2010, 398:57-67.

91. Chan MC, Hilyard AC, Wu C, Davis BN, Hill NS, Lal A, Lieberman J, Lagna G, Hata A: Molecular basis for antagonism between PDGF and the TGFbeta family of signalling pathways by control of miR-24 expression. EMBO J 2010, 29:559-573.

92. Kim YK, Yu J, Han TS, Park SY, Namkoong B, Kim DH, Hur K, Yoo MW, Lee HJ, Yang HK, Kim VN: Functional links between clustered microRNAs: suppression of cell-cycle inhibitors by microRNA clusters in gastric cancer. Nucleic Acids Res 2009, 37:1672-1681.

93. Grimson A, Farh KK, Johnston WK, Garrett-Engele P, Lim LP, Bartel DP: MicroRNA targeting specificity in mammals: determinants beyond seed pairing. Mol Cell 2007, 27:91-105.

94. Lewis BP, Burge CB, Bartel DP: Conserved seed pairing, often flanked by adenosines, indicates that thousands of human genes are microRNA targets. Cell 2005, 120:15-20.

95. Carmona-Saez P, Chagoyen M, Tirado F, Carazo JM, Pascual-Montano A: GENECODIS: a web-based tool for finding significant concurrent annotations in gene lists. Genome Biol 2007, 8:R3.

96. Nogales-Cadenas R, Carmona-Saez P, Vazquez M, Vicente C, Yang X, Tirado F, Carazo JM, Pascual-Montano A: GeneCodis: interpreting gene lists through enrichment analysis and integration of diverse biological information. Nucleic Acids Res 2009, 37:W317-322.

97. Thomas PD, Campbell MJ, Kejariwal A, Mi H, Karlak B, Daverman R, Diemer K, Muruganujan A, Narechania A: PANTHER: a library of protein families and subfamilies indexed by function. Genome Res 2003, 13:2129-2141.

98. Zaidi SK, Dowdy CR, van Wijnen AJ, Lian JB, Raza A, Stein JL, Croce CM, Stein GS: Altered Runx1 subnuclear targeting enhances myeloid cell proliferation and blocks differentiation by activating a miR-24/MKP-7/ MAPK network. Cancer Res 2009, 69:8249-8255.

99. Kiriakidou M, Nelson PT, Kouranov A, Fitziev P, Bouyioukos C, Mourelatos Z, Hatzigeorgiou A: A combined computational-experimental approach predicts human microRNA targets. Genes Dev 2004, 18:1165-1178.

100. Sun $Q$, Zhang $Y$, Yang G, Chen X, Cao G, Wang J, Sun Y, Zhang P, Fan M, Shao N, Yang $X$ : Transforming growth factor-beta-regulated miR-24 promotes skeletal muscle differentiation. Nucleic Acids Res 2008, 36:2690-2699.

101. Zuker M: Mfold web server for nucleic acid folding and hybridization prediction. Nucleic Acids Res 2003, 31:3406-3415.

102. Jiang $Q$, Wang Y, Hao Y, Juan L, Teng M, Zhang X, Li M, Wang G, Liu Y: miR2Disease: a manually curated database for microRNA deregulation in human disease. Nucleic Acids Res 2009, 37:D98-104.

103. Abu-Eneel K, Liu T, Gazzaniga FS, Nishimura Y, Wall DP, Geschwind DH, Lao K, Kosik KS: Heterogeneous dysregulation of microRNAs across the autism spectrum. Neurogenetics 2008, 9:153-161.

104. Sayed D, Hong C, Chen IY, Lypowy J, Abdellatif M: MicroRNAs play an essential role in the development of cardiac hypertrophy. Circ Res 2007, 100:416-424

105. Xi Y, Shalgi R, Fodstad O, Pilpel Y, Ju J: Differentially regulated micro-RNAs and actively translated messenger RNA transcripts by tumor suppressor p53 in colon cancer. Clin Cancer Res 2006, 12:2014-2024.

106. Ciafre SA, Galardi S, Mangiola A, Ferracin M, Liu CG, Sabatino G, Negrini M, Maira G, Croce CM, Farace MG: Extensive modulation of a set of microRNAs in primary glioblastoma. Biochem Biophys Res Commun 2005, 334:1351-1358.

107. van Rooij E, Sutherland LB, Liu N, Williams AH, McAnally J, Gerard RD, Richardson JA, Olson EN: A signature pattern of stress-responsive microRNAs that can evoke cardiac hypertrophy and heart failure. Proc Natl Acad Sci USA 2006, 103:18255-18260.

108. Chow TF, Youssef YM, Lianidou E, Romaschin AD, Honey RJ, Stewart R, Pace KT, Yousef GM: Differential expression profiling of microRNAs and their potential involvement in renal cell carcinoma pathogenesis. Clin Biochem 2010, 43:150-158.
109. Yanaihara N, Caplen N, Bowman E, Seike M, Kumamoto K, Yi M, Stephens RM, Okamoto A, Yokota J, Tanaka T, et al: Unique microRNA molecular profiles in lung cancer diagnosis and prognosis. Cancer Cell 2006, 9:189-198.

110. Dai Y, Sui W, Lan H, Yan Q, Huang H, Huang Y: Comprehensive analysis of microRNA expression patterns in renal biopsies of lupus nephritis patients. Rheumatol Int 2009, 29:749-754.

111. Schultz J, Lorenz P, Gross G, Ibrahim S, Kunz M: MicroRNA let-7b targets important cell cycle molecules in malignant melanoma cells and interferes with anchorage-independent growth. Cell Res 2008, 18:549-557.

112. Kozaki K, Imoto I, Mogi S, Omura K, Inazawa J: Exploration of tumorsuppressive microRNAs silenced by DNA hypermethylation in oral cancer. Cancer Res 2008, 68:2094-2105.

113. Bloomston M, Frankel WL, Petrocca F, Volinia S, Alder H, Hagan JP, Liu CG, Bhatt D, Taccioli C, Croce CM: MicroRNA expression patterns to differentiate pancreatic adenocarcinoma from normal pancreas and chronic pancreatitis. JAMA 2007, 297:1901-1908.

114. He H, Jazdzewski K, Li W, Liyanarachchi S, Nagy R, Volinia S, Calin GA, Liu CG, Franssila K, Suster $S$, et al: The role of microRNA genes in papillary thyroid carcinoma. Proc Natl Acad Sci USA 2005, 102:19075-19080.

115. Porkka KP, Pfeiffer MJ, Waltering KK, Vessella RL, Tammela TL, Visakorpi T: MicroRNA expression profiling in prostate cancer. Cancer Res 2007, 67:6130-6135.

116. Prueitt RL, Yi M, Hudson RS, Wallace TA, Howe TM, Yfantis HG, Lee DH, Stephens RM, Liu CG, Calin GA, et al: Expression of microRNAs and protein-coding genes associated with perineural invasion in prostate cancer. Prostate 2008, 68:1152-1164.

117. Perkins DO, Jeffries CD, Jarskog LF, Thomson JM, Woods K, Newman MA, Parker JS, Jin J, Hammond SM: microRNA expression in the prefrontal cortex of individuals with schizophrenia and schizoaffective disorder. Genome Biol 2007, 8:R27.

118. Nam EJ, Yoon H, Kim SW, Kim H, Kim YT, Kim JH, Kim JW, Kim S: MicroRNA expression profiles in serous ovarian carcinoma. Clin Cancer Res 2008, 14:2690-2695.

119. Wu F, Zikusoka M, Trindade A, Dassopoulos T, Harris ML, Bayless TM, Brant SR, Chakravarti S, Kwon JH: MicroRNAs are differentially expressed in ulcerative colitis and alter expression of macrophage inflammatory peptide-2 alpha. Gastroenterology 2008, 135:1624-1635, e1624.

120. Wang T, Zhang X, Obijuru L, Laser J, Aris V, Lee P, Mittal K, Soteropoulos P, Wei JJ: A micro-RNA signature associated with race, tumor size, and target gene activity in human uterine leiomyomas. Genes Chromosomes Cancer 2007, 46:336-347.

121. Otsuka M, Jing Q, Georgel P, New L, Chen J, Mols J, Kang YJ, Jiang Z, Du X, Cook $R$, et al: Hypersusceptibility to vesicular stomatitis virus infection in Dicer1-deficient mice is due to impaired miR24 and miR93 expression. Immunity 2007, 27:123-134.

doi:10.1186/1476-4598-9-232

Cite this article as: Chhabra et al:: Cooperative and individualistic functions of the microRNAs in the miR-23a 27a 24-2 cluster and its implication in human diseases. Molecular Cancer 2010 9:232.

\section{Submit your next manuscript to BioMed Central and take full advantage of:}

- Convenient online submission

- Thorough peer review

- No space constraints or color figure charges

- Immediate publication on acceptance

- Inclusion in PubMed, CAS, Scopus and Google Scholar

- Research which is freely available for redistribution 